\title{
The Origins of the Irish Mathematical Society
}

\author{
T. T. WEST
}

In the 1960's practically the only collective activities of the Irish mathematical community were the Christmas and Easter symposia organised by the Dublin Institute for Advanced Studies which, happily, still continue. A group of younger mathematicians, most of whose doctoral studies had taken place abroad, had returned to Ireland and were determined to change this situation. This informal group, which met in the late 1960's and consisted of J. Kennedy (U.C.D.), F. Holland (U.C.C.), D. McAlister (Q.U.B.), and T. West (T.C.D.) decided in 1967, to circulate the Irish mathematical community, north and south, to determine the possibility of organised research symposia or summer schools on selected topics. The response was very clear, meetings of this nature, provided they dovetailed with the interests of the mathematical community, would achieve widespread support and two topics (Group Representation and Quantum Mechanics) topped the list as far as overall interest was concerned. The Secretary of the Royal Irish Academy, Fr. J. R. Mc Connell, then took up the case put forward by the informal group and suggested that if the meetings were to be organised under the auspices of the Academy it would be easier to obtain the support of all Irish Universities. Father Mc Connell went further and suggested that the informal group would be constituted an Academy SubCommittee of the Irish National Committee for Mathematics and the fact that the Royal Irish Academy's role was recognised all over Ireland made this proposition attractive. This was immediately agreed to and the Summer School SubCommittee of the Academy's National Committee for Mathematics came into existence. Thus the first meeting, a Summer School on Group Representations and Quantum Mechanics was organised in T.C.D. by T.T. West from 7-18 July, 1969. 
Financial support was forthcoming from all the Irish universities. The topic had been chosen to appeal to the whole mathematical community, pure and applied, and an attendance of 98 testified to the popularity of the Summer School; a modest credit balance of $£ 300$ offering the possibility of seed funding for future symposia. The director in his report, commented that "the success of the Summer School firmly justifies the confidence of the Summer School SubCommittee that its efforts would be supported and would produce a real stimulus for Irish Mathematics". One of the benefits of operating under the umbrella of the Royal Irish Academy was that its National Committee for Mathematics was the Irish body recognised by the International Mathematical Union, indeed financial support for the first Summer School was forthcoming from the I.M.U.

Using the same format a Summer School on Complex Function Theory directed by F. Holland was held in U.C.C. on 19-24 July,1971. A Conference on Numerical Analysis, directed by J.J. H. Miller, was held in U.C.D. from 14-18 August, 1972 whose proceedings were published by Academic Press. A Summer School on Group Theory and Computation, directed by M.P.J. Curran, was held in U.C.G. from 16-21 July, 1973 and a Symposium on Spectral Theory directed by T.T. West was held in T.C.D. from 12-15 March, 1974. During this Symposium the Larmor Lecture of the Academy was delivered by Prof. B. Sz. Nagy of Hungary, who had recently been elected an Honorary Member of the Academy, and the Symposium Proceedings, consisting of 19 papers, was published as a single volume of Proceedings of the R.I.A., section A. dealing with mathematics and physics. Two further Conferences on Numerical Analysis, directed by J.J.H. Miller, were held in 1974 and 1976 and a Symposium on Harmonic Analysis and Topological Algebra held in T.C.D. from 16 to 19 December, 1975 was directed by T.T. West. The proceedings of this latter Symposium were again published as a single volume in section A of the Proceedings of the R.I.A. At a reception for the participants in Academy House presentations were made by Prof. D. Greene, the President of the Academy, to two distinguished British analysts, G. Brown and W. Moran, who had developed strong connections with Irish Mathematicians prior to their departure to chairs in Australia.

The SubCommittee issued a mathematical newsletter, edited by T.T. West, twice yearly commencing in 1974, this ultimately ran to 4 issues. At a meeting held in 39 T.C.D. during the D.I.A.S. 
Symposium of December, 1975 a decision was taken to form the Irish Mathematical Society and a small group consisting of D. Mc Quillan (U.C.D.), J.T. Lewis (D.I.A.S.) and T. West was appointed to draw up a draft constitution. This constitution, which was based on that of the Edinburgh Mathematical Society, was accepted at a further meeting held in 39 T.C.D. on 14 April, 1976 following the D.I.A.S. Easter Symposium. The subscription rates were fixed at $£ 2$ for ordinary members and 50 pence for students. Thus the I.M.S. was born. One further benefit which accrued from the organisation of these conferences, symposia and Summer Schools was the decision of the Royal Irish Academy to publish two parts of each volume of section A of the Academy's Proceedings annually, instead of the then current practice of publishing papers separately. It was also clear that there were considerable benefits to be obtained from holding future meetings under the joint auspices of the Royal Irish Academy and the Irish Mathematical Society.

T. T. West,

School of Mathematics,

Trinity College Dublin,

Dublin, Ireland

west@maths.tcd.ie

Received 23 January 2003. 